\title{
2-Aminophenoxazine-3-one induces cellular apoptosis by causing rapid intracellular acidification and generating reactive oxygen species in human lung adenocarcinoma cells
}

\author{
CHUN-LEI ZHENG ${ }^{1 *}$, XIAO-FANG CHE ${ }^{2 *}$, SHIN-ICHI AKIYAMA ${ }^{2}$, KEISUKE MIYAZAWA $^{3}$ and AKIO TOMODA ${ }^{3}$ \\ ${ }^{1}$ Department of Medical Oncology, Cancer Hospital, Fudan University, 270 Dong An Road, 200032, \\ Shanghai, China; ${ }^{2}$ Department of Molecular Oncology, Advanced Therapeutics, Kagoshima University, \\ Graduate School of Medical and Dental Sciences, Kagoshima 890-8544; ${ }^{3}$ Department of Biochemistry, \\ Tokyo Medical University, 6-1-1 Shinjuku, Tokyo 160-8402, Japan
}

Received October 20, 2009; Accepted December 18, 2009

DOI: 10.3892/ijo_00000540

\begin{abstract}
Aminophenoxazine-3-one (Phx-3)-induced apoptosis was investigated. Phx-3 suppressed the viability of human lung adenocarcinoma cell line A549 and induced cellular apoptosis $6 \mathrm{~h}$ after treatment. Prior to these events, intracellular $\mathrm{pH}(\mathrm{pHi})$ was rapidly decreased from $\mathrm{pH} 7.65$ to 7.10 within 30 min when A549 cells were treated with $7 \mu \mathrm{M}$ $\mathrm{Phx}-3$. This intracellular acidification continued for $3 \mathrm{~h}$ in the cells. Augmented production of reactive oxygen species (ROS) was obseved $1 \mathrm{~h}$ after treatment of A549 cells with $7 \mu \mathrm{M}$ Phx-3, and cell cycle arrest at $\mathrm{G}_{1}$ was indicated $3 \mathrm{~h}$ after treatment. The translocation of NF- $\mathrm{KB}$ from the cytosol to the nucleus was clearly indicated $1 \mathrm{~h}$ after the administration of Phx-3 to A549 cells, while it was significantly suppressed when Nac, a scavenger of ROS, was added to the cells with Phx-3. The Phx-3-induced apoptosis in A549 cells was significantly suppressed when Nac was administered to the cells. These results suggest that a decrease of $\mathrm{pHi}$, caused by depolarization of the mitochondria, may trigger the dysfunction of mitochondria causing ROS production; therefore, both the translocation of NF- $\mathrm{KB}$ from the cytoplasm to the nucleus and apoptosis induction were promoted in A549 cells. Microscopic examination of the cellular localization of $\mathrm{Phx}-3$ in A549 cells revealed that $\mathrm{Phx}-3$ was mainly localized in the cytoplasm and the mitochondria, but not in the nucleus. The present results indicate that Phx-3 might be a strong anticancer drug against lung cancer, which is intractable to chemotherapy, by causing various early
\end{abstract}

Correspondence to: Dr Akio Tomoda, Department of Biochemistry, Tokyo Medical University, 6-1-1 Shinjuku, Tokyo 160-8402, Japan

E-mail: tomoda@tokyo-med.ac.jp

*Contributed equally

Key words: 2-aminophenoxazine-3-one, A549 cells, intracellular $\mathrm{pH}$, reactive oxygen species, $\mathrm{NF}-\mathrm{\kappa B}$ events, including the decrease of pHi and ROS production, and finally inducing cellular apoptosis.

\section{Introduction}

Intracellular $\mathrm{pH}(\mathrm{pHi})$, which is essential to maintain normal cell function, is strictly controlled within a narrow range $(1,2)$. The typical case for this is human erythrocytes, where $\mathrm{pHi}$ is maintained at $\mathrm{pH} \mathrm{7.2,} \mathrm{in} \mathrm{spite} \mathrm{of} \mathrm{higher} \mathrm{pH}$ of the plasma or the interstitial fluid (usually $\mathrm{pH} 7.4)(3,4)$. However, it has been postulated that $\mathrm{pHi}$ in cancer cells is maintained higher to avoid apoptosis (5), because cellular acidosis has been found to be a trigger in the early phase of apoptosis, leading to the activation of endonuclease II to induce DNA fragmentation. Regardless of these facts, few reports have dealt with the pHi in cancer cells (6-8).

Higher $\mathrm{pHi}$ seems to be favorable for the tumorigenesis $(2,9)$ and proliferation of cancer cells $(10)$. In contrast, cellular acidification induces the activation of endonuclease II, which causes the fragmentation of DNA and dysfunction of mitochondria (11-13), leading to the increased production of reactive oxygen species (ROS) (2), which affects the translocation of nuclear factor- $\kappa \mathrm{B}(\mathrm{NF}-\kappa \mathrm{B})(14,15)$ and cellular apoptosis $(16,17)$. Matsuyama et al (11) demonstrated that mitochondria-dependent apoptotic stimuli such as staurosporine and ultraviolet irradiation induce cytosolic acidification with subsequent release of cytochrome c, caspase activation and mitochondrial depolarization. Therefore, drugs to decrease the pHi in cancer cells are expected to induce apoptosis of cancer cells by perturbing intracellular homeostasis and metabolism. However, anti-cancer agents that induce apoptosis by lowering $\mathrm{pHi}$ have been rarely reported.

Phenoxazine compounds including 2-amino-4, $4 \alpha$-dihydro$\alpha$, 7-dimethyl-3H-phenoxazine-3-one (Phx-1), and 2-aminophenoxazine-3-one (Phx-3), which are synthesized by the reactions of o-aminophenols with bovine hemoglobin $(18,19)$, are oxidative phenoxazines like actinomycin D (20) and exert anticancer activity against various cancer cells in vitro and in vivo, promoting cellular apoptosis (21-23). Phx-3 caused 
caspase-dependent apoptosis in multiple myeloma cells (24), and caspase-independent apoptosis in neuroblastoma cells, glioma cells and gastric cancer cells (25-27). However, it remains unclear how pHi is affected, and how ROS and NF-кB are implicated in the apoptosis of cancer cells in the presence of Phx-3. Moreover, the activation of NF- $\mathrm{BB}$ is affected by various intracellular events, such as the production of ROS $(14,15)$ and changes in cytoplasmic homeostasis, and acts in either antiapoptotic or proapoptotic manner according to cellular conditions $(28,29)$. Hence, it is important to examine how ROS and $\mathrm{NF}-\kappa \mathrm{B}$ are involved in apoptosis in cancer cells with $\mathrm{Phx}-3$.

In this study, we investigated the anticancer effects of Phx-3 on human lung adenocarcinoma cell line A549, with special attention to the causal relationship of $\mathrm{pHi}$ change with ROS production, NF- $\kappa \mathrm{B}$ activation, and apoptosis induction in the cells.

\section{Materials and methods}

Phx-3 and other reagents. For this study, Phx-3 was prepared according to the method described by Shimizu et al (19). Chemical structure of Phx-3 is depicted in Fig. 1. Phx-3 was dissolved in a mixture of dimethylsulfoxide (DMSO) and ethyl alcohol (3:1) as a vehicle to make $20 \mathrm{mM}$ solution. Sodium arsenite $\left(\mathrm{NaAsO}_{2}\right.$, AsIII) was obtained from Wako Pure Chemical (Osaka, Japan) and dissolved in distilled water. Cisplatin (CDDP) (Sigma, St. Louis, MO) was dissolved in DMSO. Acridine orange (AO) and $\mathrm{N}$-acetylcysteine (Nac) were purchased from Sigma. MG-132 and Bay 11-7082 were purchased from Calbiochem (a brand of Merck KGaA, Darmstadt, Germany).

Cell line and culture condition. Human lung adenocarcinoma cell line A549, which was obtained from the Health Science Research Resources Bank (Osaka, Japan), was cultured in DMEM (Nissui Seiyaku Co.) supplemented with $10 \%$ fetal calf serum (Equitech-Bio, Kerrville, TX), $2 \mathrm{mM}$ glutamine, and $100 \mathrm{U} / \mathrm{ml}$ of penicillin at $37^{\circ} \mathrm{C}$ in a $5 \% \mathrm{CO}_{2}$ humidified atmosphere.

Estimation of viability of A549 cells treated with various concentrations of Phx-3, arsenite, or CDDP. A549 cells $(3,000 / \mathrm{ml})$ were incubated with or without various concentrations of Phx-3, arsenite, or CDDP for $72 \mathrm{~h}$ in 96-well plates. Next, 3-(4,5-dimethylthiazolyl-2)-2,5-diphenyltetrazolium bromide (MTT) solution $(5 \mathrm{mg} / \mathrm{ml})$ was added to each well, and the plates were incubated for an additional $4 \mathrm{~h}$. The MTT formazan precipitate was dissolved in $100 \mu \mathrm{l}$ of DMSO after aspiration of the culture medium. The plates were shaken for $5 \mathrm{~min}$ and read immediately at $570 \mathrm{~nm}$ using a model 550 Micro Plate Reader (Bio-Rad, Hercules, CA).

Apoptosis and necrosis detection. Apoptotic and necrotic cells were quantitatively evaluated by flow cytometry using the Annexin V-Fluorescein Staining Kit (Wako Pure Chemical). A549 cells $\left(2 \times 10^{5}\right)$ were treated with $7 \mu \mathrm{M}$ Phx-3 for the indicated time in the presence or absence of 20 or $40 \mu \mathrm{M}$ MG132, 10 or $20 \mu \mathrm{M}$ Bay 11-7082, or 5 or $20 \mathrm{mM} \mathrm{Nac}$. The cells were harvested and washed once with PBS (pH 7.4). An

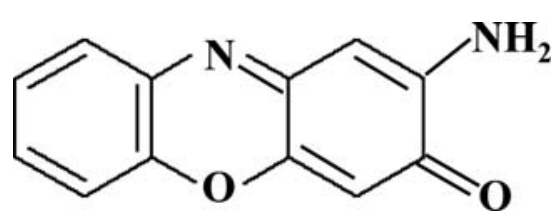

Figure 1. Chemical structure of Phx-3.

aliquot of $100 \mu \mathrm{l}$ of cell suspension was stained with $2 \mu \mathrm{l}$ of annexin $\mathrm{V}$ and $20 \mu \mathrm{l}$ propidium iodide (PI). Samples were incubated for $15 \mathrm{~min}$ at room temperature, after which $400 \mu \mathrm{l}$ of binding buffer was added. The levels of fluorescent staining of the cells were analyzed using a Coulter FACScan (BectonDickinson, San Jose, CA) to estimate the population of the early apoptotic cells (annexin $\mathrm{V}^{+} / \mathrm{PI}^{-}$), the late apoptotic cells (annexin $\mathrm{V}^{+} / \mathrm{PI}^{+}$), and the necrotic cells (annexin $\mathrm{V}^{-} / \mathrm{PI}^{+}$) in A549 cells treated with or without Phx-3.

Cell cycle analysis by flow cytometry. A549 cells were treated with $7 \mu \mathrm{M}$ Phx-3 for $0,1,3$ and $6 \mathrm{~h}$. The cells were harvested, washed once with PBS, suspended in $50 \mu \mathrm{l}$ PBS, and mixed with $50 \mu 1$ Coulter DNA-prep LRP (Coulter, Miami, FL), and $1 \mathrm{ml}$ Coulter DNA-prep Stain solution was added. The mixtures were then incubated at room temperature for $15 \mathrm{~min}$. The cell cycle was analyzed using a Coulter FACScan (Becton-Dickinson).

Determination of pHi. A549 cell pHi was determined according to the method described by Litman et al (6). Briefly, A549 cells $\left(4 \times 10^{7} / \mathrm{ml}\right)$ were loaded with the $\mathrm{pH}$ sensitive fluorescent probe BCECF-AM (3 $\mu \mathrm{M}$ ) (Dojin Chemical, Kumamoto, Japan) in HEPES buffer (153 mM $\mathrm{NaCl}, 5 \mathrm{mM} \mathrm{KCl}, 5 \mathrm{mM}$ glucose, $20 \mathrm{mM}$ HEPES, $\mathrm{pH}$ 7.4) at $37^{\circ} \mathrm{C}$ for $30 \mathrm{~min}$. After being washed once with HEPES buffer, the cells were resuspended in HEPES buffer. The cells $\left(3 \times 10^{6}\right)$ were treated with or without various concentrations of $7 \mu \mathrm{M} \mathrm{Phx}-3$ for $0,1,2,5,10,20$ and $30 \mathrm{~min}$. Fluorescence was measured at an excitation wavelength of $500 \mathrm{~nm}$ and an emission wavelength of $530 \mathrm{~nm}$, using a FP750 microplate fluorescence reader (Jasco, Tokyo). To calibrate fluorescence, BCECF-AM-loaded cells $\left(3 \times 10^{6}\right)$ were suspended in $\mathrm{pH} 6.6,7.2,7.4,7.8$ and 8.0 calibration buffer $\left(130 \mathrm{mM} \mathrm{KCl}, 10 \mathrm{mM} \mathrm{NaCl}, 1 \mathrm{mM} \mathrm{MgSO}_{4}, 10 \mathrm{mM}\right.$ $\mathrm{Na}-\mathrm{MOPS}$ ) and $10 \mu \mathrm{g} / \mathrm{ml}$ nigericin was added to equilibrate the external and internal $\mathrm{pH}$. The relative fluorescence ratio values were plotted against corresponding pHi values, which allowed the determination of the unknown pHi. A linear calibration curve for $\mathrm{pHi}$ was obtained (data not shown), i.e., the optical density of the solution including BCECF-AM increased linearly, with an increase of the $\mathrm{pH}$. Therefore, it was possible to estimate the pHi of A549 cells loaded with BCECF-AM.

Influence of Phx-3 on the pHi in A549 cells. Acridine orange (AO) is a weak basic fluorescence probe that accumulates in the acidic organelles and emits red fluorescence at low $\mathrm{pH}$ and green fluorescence at high $\mathrm{pH}$. We applied this characteristic of $\mathrm{AO}$ to detect the influence of $\mathrm{Phx}-3$ on the pHi in A549 cells by FACS. For the FACS, A549 cells were 

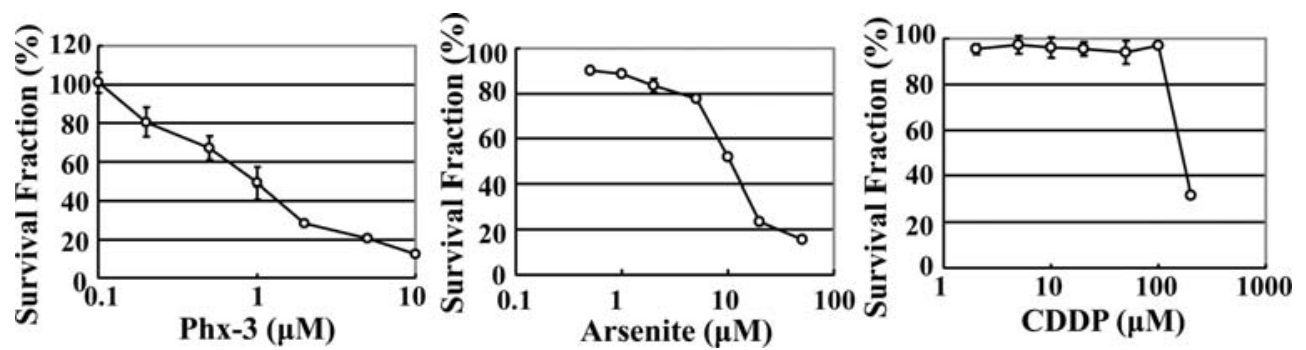

Figure 2. Effects of Phx-3, arsenite and cisplatin (CDDP) on the viability of A549 cells. A549 cells were treated with different concentrations of Phx-3, arsenite and CDDP for $72 \mathrm{~h}$. Survival fraction (\%) of A549 cells was depicted as a function of concentrations of these compounds.

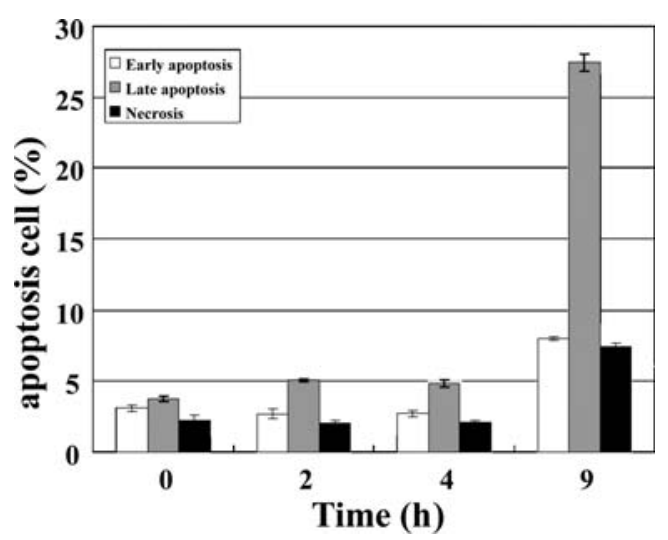

Figure 3. Population of cells with early apoptosis, late apoptosis and necrosis in A549 cells treated with $7 \mu \mathrm{M} \mathrm{Phx}-3$ for $0,2,4$ and $6 \mathrm{~h}$. Population of cells with early apoptosis (annexin $\mathrm{V}^{+} / \mathrm{PI}^{-}$), late apoptosis (annexin $\mathrm{V}^{+} / \mathrm{PI}^{+}$), and necrosis (annexin $\mathrm{V}^{-} / \mathrm{PI}^{+}$) in A549 cells was analyzed by flow cytometric method.

incubated with or without $7 \mu \mathrm{M}$ of $\mathrm{Phx}-3$ for $2.5 \mathrm{~h}$ at $37^{\circ} \mathrm{C}$, incubated with $6 \mu \mathrm{M}$ AO for another $30 \mathrm{~min}$, washed twice with PBS, and resuspended in $1 \mathrm{ml}$ PBS. The level of fluorescent staining of the cells was analyzed using a Coulter FACScan (Becton-Dickinson). When pHi became acidic in the cells, the cells gave off orange fluorescence, whereas alkaline pHi cells gave off green fluorescence.

Observation of Phx-3 localization by laser scanning confocal microscopy $\left(\right.$ LSCM). A549 cells $\left(4 \times 10^{3} / \mathrm{ml}\right)$ were seeded per well in a 48-well glass-bottom plate and grown to subconfluency. They were incubated with or without 50 or $100 \mu \mathrm{M}$ Phx-3 with growth medium containing $200 \mathrm{nM}$ MitoTracker Red CMXRos (molecular probes) for mitochondria staining and $2 \mu \mathrm{g} / \mathrm{ml}$ Hoechst 33342 (molecular probes) for nuclei staining at $37^{\circ} \mathrm{C}$ for $45 \mathrm{~min}$. After washing with $\mathrm{PBS}$, the cells were examined by confocal fluorescence microscopy (FV500, Olympus Corporation).

Detection of intracellular ROS. ROS production was determined using 2',7'-dichlorodihydrofluorescein diacetate ( $\left.\mathrm{H}_{2} \mathrm{DCFDA}\right)$ (Molecules Probes, Eugene, OR, USA). The $\mathrm{H}_{2}$ DCFDA diffuses through the cell membrane and is hydrolyzed by esterases to non-fluorescent dichlorofluorescein (DCFH) in cells. In the presence of ROS, this compound is oxidized to highly-fluorescent dichlorofluorescein (DCF) in cells. For these experiments, A549 cells were seeded in a
12 -well plate at $2 \times 10^{5}$ cells/well. At $16 \mathrm{~h}$ after plating, the cells were treated with $7 \mu \mathrm{M}$ Phx-3 and incubated at $37^{\circ} \mathrm{C}$ for $2.5 \mathrm{~h}$ with or without $5 \mathrm{mM}$ or $20 \mathrm{mM} \mathrm{Nac}$. The cells were then incubated with $10 \mu \mathrm{M} \mathrm{H}_{2}$ DCFDA for an additional $30 \mathrm{~min}$ at $37^{\circ} \mathrm{C}$. The cells were next trypsinized and washed twice with ice-cold phosphate-buffered saline (PBS). Fluorescence was quantified by flow cytometry using a Coulter FACScan (Becton-Dickinson).

Effects of Phx-3 on $N F-\kappa B$ levels in the cytoplasm and the nucleus in A549 cells. After treatment with $\mathrm{Phx}-3$ in the absence or presence of Nac, MG132, or Bay 11-7082 for 0, 1, 3, 6 and 9 h, A549 cells were harvested and lysed in $400 \mu \mathrm{l}$ lysis buffer; buffer A, containing $10 \mathrm{mM}$ HEPES (pH 7.9), $10 \mathrm{mM} \mathrm{KCl}, 0.2 \mathrm{mM}$ EDTA, $1 \mathrm{mM}$ dithiothreitol, $0.5 \mathrm{mM}$ $p$-APMSF [( $p$-amidinophenyl)-methanesulfonyl fluoride hydrochloride], and $0.6 \%$ NP-40. The lysates were centrifuged at $250 \mathrm{x}$ g for $10 \mathrm{~min}$. The supernatant was then collected as the cytoplasmic fraction. The pellets containing the nuclei were washed in buffer A without NP-40 and resuspended in $50 \mu 1$ nuclear lysis buffer [buffer C, containing $20 \mathrm{mM}$ HEPES (pH 7.9), $0.4 \mathrm{M} \mathrm{NaCl}, 2 \mathrm{mM}$ EDTA, $1 \mathrm{mM}$ dithiothreitol and $1 \mathrm{mM}$ PMSF], incubated for $30 \mathrm{~min}$ at $4^{\circ} \mathrm{C}$, and centrifuged at 20,000 x g for $20 \mathrm{~min}$. The supernatants were either used as nuclear fractions immediately or stored at $-80^{\circ} \mathrm{C}$ until use. The protein concentration was determined by a Bio-Rad protein assay according to the manufacturer's protocol (BioRad Laboratories, Hercules, CA). Lysates containing $100 \mu \mathrm{g}$ of protein were subjected to $9.4 \%$ SDS-polyacrylamide gel electrophoresis (SDS-PAGE) and then transferred to an Immobilon-P membrane (Millipore, Bedford, MA). The membrane was incubated with the primary antibody (dilution of 1:1000) of p65, p50, phospho-p65 and $\alpha$-tubulin, which was used as a loading control, overnight at $4^{\circ} \mathrm{C}$ and then with a peroxidase-linked secondary antibody (dilution of 1:2000) at room temperature for $1 \mathrm{~h}$; the proteins were subsequently visualized by enhanced chemiluminescence.

\section{Results}

Effect of Phx-3 on the viability, apoptosis and cell cycle distribution in A549 cells. We studied the cytotoxicity of Phx-3 on human lung adenocarcinoma cell line A549 and compared it with that of arsenite and cisplatin (CDDP). Fig. 2 indicates the effects of different concentrations of $\mathrm{Phx}-3$, arsenite and CDDP on the viability of A549 cells that were incubated for $72 \mathrm{~h}$. The viability of A549 cells was 
(A)

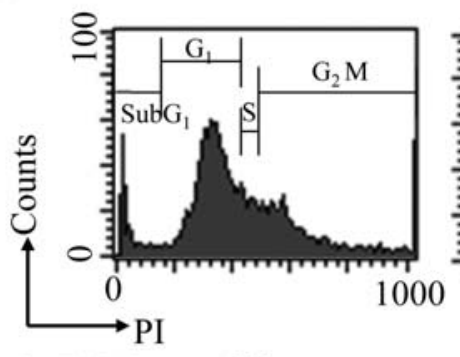

$\mathrm{Phx}-37 \mu \mathrm{M}$

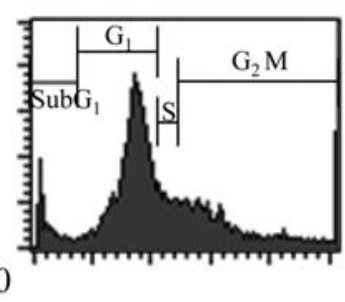

$1 \mathrm{~h}$

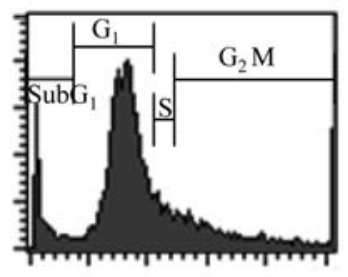

$3 \mathrm{~h}$

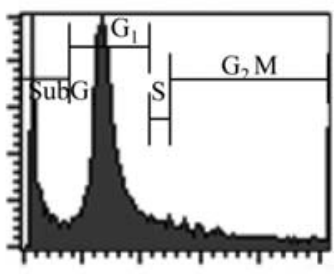

$6 \mathrm{~h}$

(B)

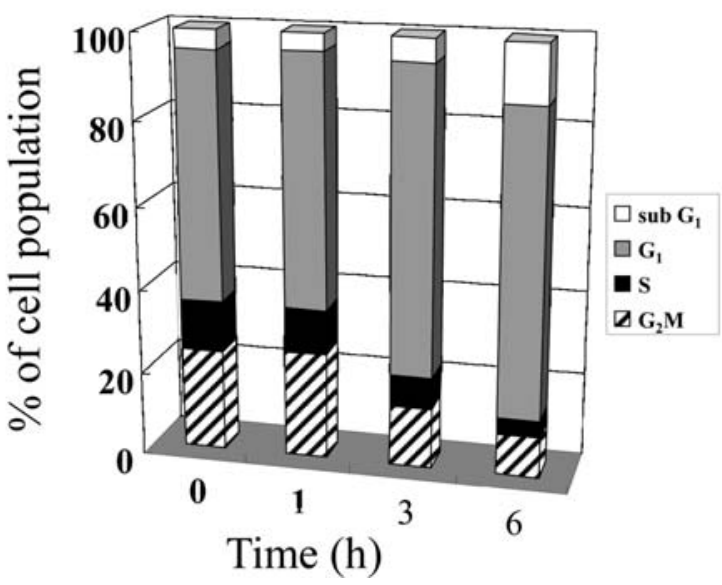

(C)

\begin{tabular}{ccccc}
\hline Time (h) & sub G1 & G1 & \multicolumn{1}{c}{ S } & G2M \\
\hline 0 & 4.38 & 59.59 & 12.21 & 24.27 \\
1 & 3.77 & 60.17 & 10.79 & 25.27 \\
3 & 5.3 & 73 & 7.49 & 14.46 \\
6 & 13.57 & 72.8 & 4.07 & 9.73 \\
\hline
\end{tabular}

Figure 4. Effects of Phx-3 on the cell cycle in A549 cells. The population of each cell cycle phase including sub- $\mathrm{G}_{1}$, $\mathrm{G}_{1}, \mathrm{~S}$ and $\mathrm{G}_{2} \mathrm{M}$ in $\mathrm{A} 549$ cells after treatment with $7 \mu \mathrm{M}$ Phx-3 was analyzed by a flow cytometric method. (A) Results of flow cytometric analysis. (B) Diagram of the population of each cell cycle phase including sub- $\mathrm{G}_{1}, \mathrm{G}_{1}, \mathrm{~S}$ and $\mathrm{G}_{2} \mathrm{M}$ as a function of time. (C) Table for the results in (B).

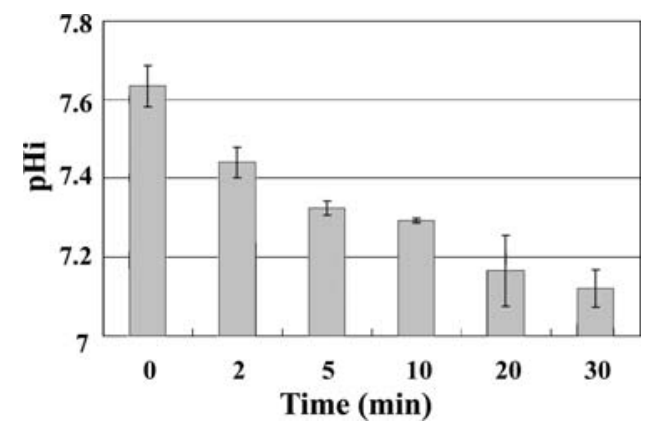

Figure 5. Changes in pHi in A549 cells during 30 min treatment with Phx-3.

significantly dose-dependently suppressed by these compounds. The $\mathrm{IC}_{50}$ of $\mathrm{Phx}-3$ against $\mathrm{A} 549$ cells was 1 $\mu \mathrm{M}$; that of arsenite was $12 \mu \mathrm{M}$; and that of CDDP was 172 $\mu \mathrm{M}$, indicating that $\mathrm{Phx}-3$ exhibited much stronger anticancer effects on A549 cells than arsenite or CDDP.

Since the viability of A549 cells was almost completely suppressed at concentrations exceeding $7 \mu \mathrm{M}$ of Phx-3, we investigated the mechanism for the anticancer effects of Phx-3 against A549 cells at $7 \mu \mathrm{M}$ under various conditions. In order to examine whether augmented suppression of the viability of A549 cells was related to the apoptotic mechanism, A549 cells were treated with $7 \mu \mathrm{M} \mathrm{Phx}-3$ for $0,2,4$ or $9 \mathrm{~h}$, and the population of apoptotic cells was quantified using annexin
V-FITC and PI staining by flow cytometry. When cells were treated with Phx-3 for $9 \mathrm{~h}$, a significant increase of the percentage of late apoptotic cells (annexin $\mathrm{V}^{+} / \mathrm{PI}^{+}$) could be detected (Fig. 3).

To examine whether Phx-3 arrests cell cycle at a specific phase, the cell cycle of A549 cells was examined by flow cytometry (Fig. 4A). As shown in the diagram of Fig. 4B, Phx-3 caused arrest at the $\mathrm{G}_{1}$ phase in A549 cells in a timedependent manner, in particular after $3 \mathrm{~h}$. The population of A549 cells at the $\mathrm{G}_{1}$ phase increased from 59.6 to $73.0 \%$ at $3 \mathrm{~h}$, and $72.8 \%$ at $6 \mathrm{~h}$ (Fig. 4C). These results indicated that the apoptosis of A549 cells caused by Phx-3 (Fig. 3) occurred after the cell cycle arrest at the $\mathrm{G}_{1}$ phase (Fig. 4C) in the cells. In addition, the proportion of sub- $\mathrm{G}_{1}$ fraction increased from 4.4 to $13.6 \%$ after treatment with Phx-3 for $6 \mathrm{~h}$, demonstrating that the apoptotic cells increased at this time, confirming the results in Fig. 3.

Decrease of pHi in A549 cells treated with Phx-3, and localization of Phx-3 in the cells. Since pHi has been indicated to be involved in the homeostatic maintenance of cancer cells as well as normal cells (2-4), it is possible that changes in the pHi of A549 cells may trigger apoptosis in the cells. Thus, we investigated whether Phx-3 could influence the pHi of A549 cells. As a result, the pHi of A549 cells (pHi 7.63) without Phx-3 was greatly higher than that of normal cells such as erythrocytes (generally, pHi 7.2 in normal cells) $(3,4)$ 
(A)

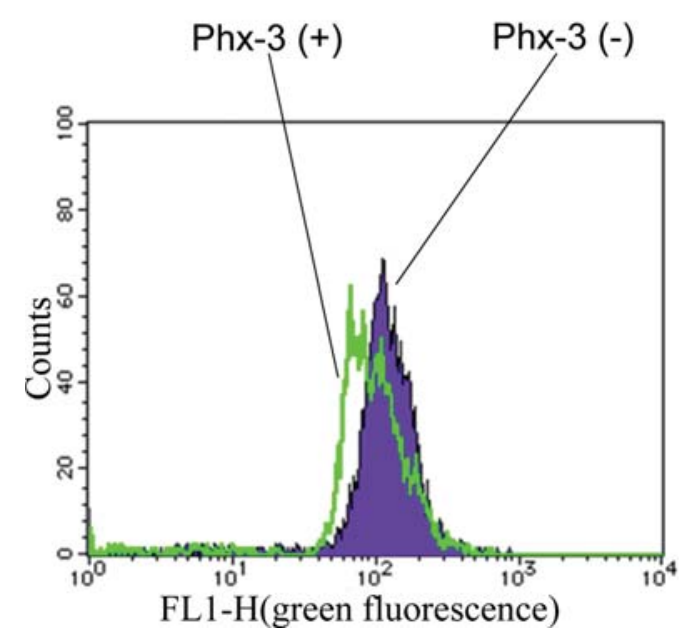

(B)

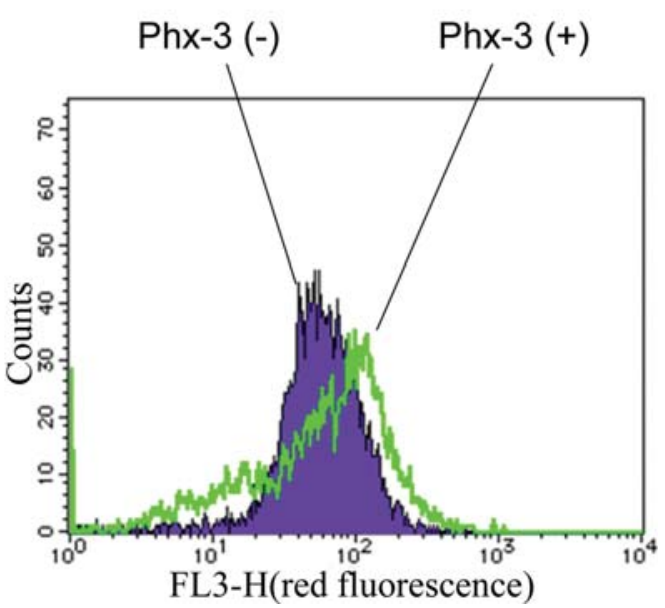

Figure 6. Intracellular acidification of A549 cells treated with Phx-3 for $3 \mathrm{~h}$. The A549 cells were treated with $7 \mu \mathrm{M}$ Phx-3 for $2.5 \mathrm{~h}$, then treated with acridine orange (AO) for another $30 \mathrm{~min}$. The pHi was measured by detecting the influence of Phx-3 on the pHi of A549 by a flow cytometric method. (A) Green fluorescence in A549 cells, in the presence or absence of Phx-3. (B) Red fluorescence in A549 cells, in the presence or absence of Phx-3.

(Fig. 5). After $7 \mu \mathrm{M}$ of Phx-3 was added to A549 cells, pHi drastically decreased from 7.63 to 7.1 within $30 \mathrm{~min}$.

We assessed the pHi of A549 cells $3 \mathrm{~h}$ after adding $7 \mu \mathrm{M}$ Phx-3 using AO, which emits red fluorescence at low $\mathrm{pH}$ and green fluorescence at high $\mathrm{pH}$. The peak of FL1-H (green fluorescent channel) shifted to the left (Fig. 6A) and the peak of FL3-H (red fluorescent channel) shifted to the right (Fig. 6B) in A549 cells with $\mathrm{Phx}-3$. The pHi was thus more acidic in A549 cells with Phx-3 than in cells without Phx-3, even $3 \mathrm{~h}$ after adding Phx-3 to the cells, and the intracellular acidification in A549 cells continued for $3 \mathrm{~h}$ in the presence of Phx-3.

Since Phx-3 emits weak green fluorescence, we examined the localization of this compound in A549 cells by using LSCM. Weak green fluorescence was visualized in the cells with $50 \mu \mathrm{M}$ Phx-3 (Fig. 7A). It stayed mainly in the cytoplasm but did not penetrate into the nucleus. In addition, Phx-3 also stayed in the mitochondria (Merge, in the presence of $50 \mu \mathrm{M}$ Phx-3; magnification, x3000, in Fig. 7A). Thus, we examined whether or not Phx-3 may be localized in the mitochondria of A549 cells, by staining the mitochondria with the highlyspecific probe MitoTracker $30 \mathrm{~min}$ after treating the cells with $100 \mu \mathrm{M}$ Phx-3. Fig. 7B clearly indicates that Phx-3 is co-localized with MitoTracker in the mitochondria in the A549 cells (Merge, in the presence of $100 \mu \mathrm{M} \mathrm{Phx}-3$; magnification, $x 3000$, in Fig. 7B). These results indicate that Phx-3 may be incorporated into the mitochondria, by way of the cytoplasm, and thereby may induce dysfunction of the mitochondria, finally causing apoptosis in A549 cells.

Generation of ROS in A549 cells treated with Phx-3. Mitochondrial ROS production is a very early event preceding the collapse of the mitochondrial membrane potential, the release of the pro-apoptotic factors, and the activation of caspases to induce apoptosis. Since $\mathrm{Phx}-3$ rapidly decreased $\mathrm{pHi}$ and localized in the mitochondria as described above, it is possible that Phx-3 may induce ROS generation in A549 cells. Thus, we studied the ROS levels detecting the fluorescence of
$\mathrm{H}_{2}$ DCFDA. In consequence, the fluorescence increased timedependently, when A549 cells were treated with $7 \mu \mathrm{M}$ Phx-3 for $3 \mathrm{~h}$ (Fig. 8). Such increase of ROS in A549 cells caused by Phx-3 was significantly inhibited by adding 5 and $20 \mathrm{mM}$ Nac, a scavenger of ROS. These results demonstrate that ROS is produced early prior to the induction of apoptosis in A549 cells treated with Phx-3.

Furthermore, we studied whether or not ROS is involved in apoptosis induction in A549 cells treated with Phx-3. Fig. 9 indicates the population of late apoptotic cells in A549 cells treated with $7 \mu \mathrm{M} \mathrm{Phx}-3$ in the presence or absence of Nac for $6 \mathrm{~h}$. The population of the late apoptotic cells increased significantly $6 \mathrm{~h}$ after the addition of Phx-3 to A549 cells but was greatly reduced by Nac, a scavenger of ROS. These results demonstrate that apoptosis was induced within $6 \mathrm{~h}$ in A549 cells with Phx-3, and was strongly influenced by the production of ROS in the cells.

Activation of $N F-\kappa B$ by ROS generation and antiapoptotic role of $N F-\kappa B$ in A549 cells treated with Phx-3. The activation of $N F-\kappa B$ is crucial for the proliferation of malignant cells, plays antiapoptotic roles, and is caused by ROS production in cells (29). We thus investigated whether NF-кB is activated by the generation of ROS and whether the activation of NF- $\mathrm{KB}$ is associated with the apoptosis of A549 cells induced by $\mathrm{Phx}-3 . \mathrm{NF}-\kappa \mathrm{B}$ heterodimer p65:p50 is retained in the cytoplasm in an inactive form primarily

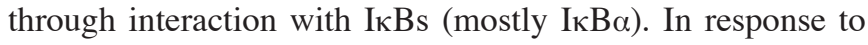
diverse stimuli, I $\mathrm{B} \mathrm{B} \alpha$ is phosphorylated and decomposed by the proteasome, resulting in the translocation of $\mathrm{NF}_{-} \kappa \mathrm{B}$ heterodimer p65-p50 to the nucleus and in binding to specific regions of DNA, which in turn results in gene transcription (29). Therefore, we examined the alteration of p65, p-p65, p50 level in the cytosol, and the nucleus extracted from A549 cells treated with $7 \mu \mathrm{M}$ Phx-3. Fig. 10A shows immunoblotting analysis of the level of p65 and p50 in the cytosol and the nucleus, in A549 cells treated with Phx-3, indicating 
A

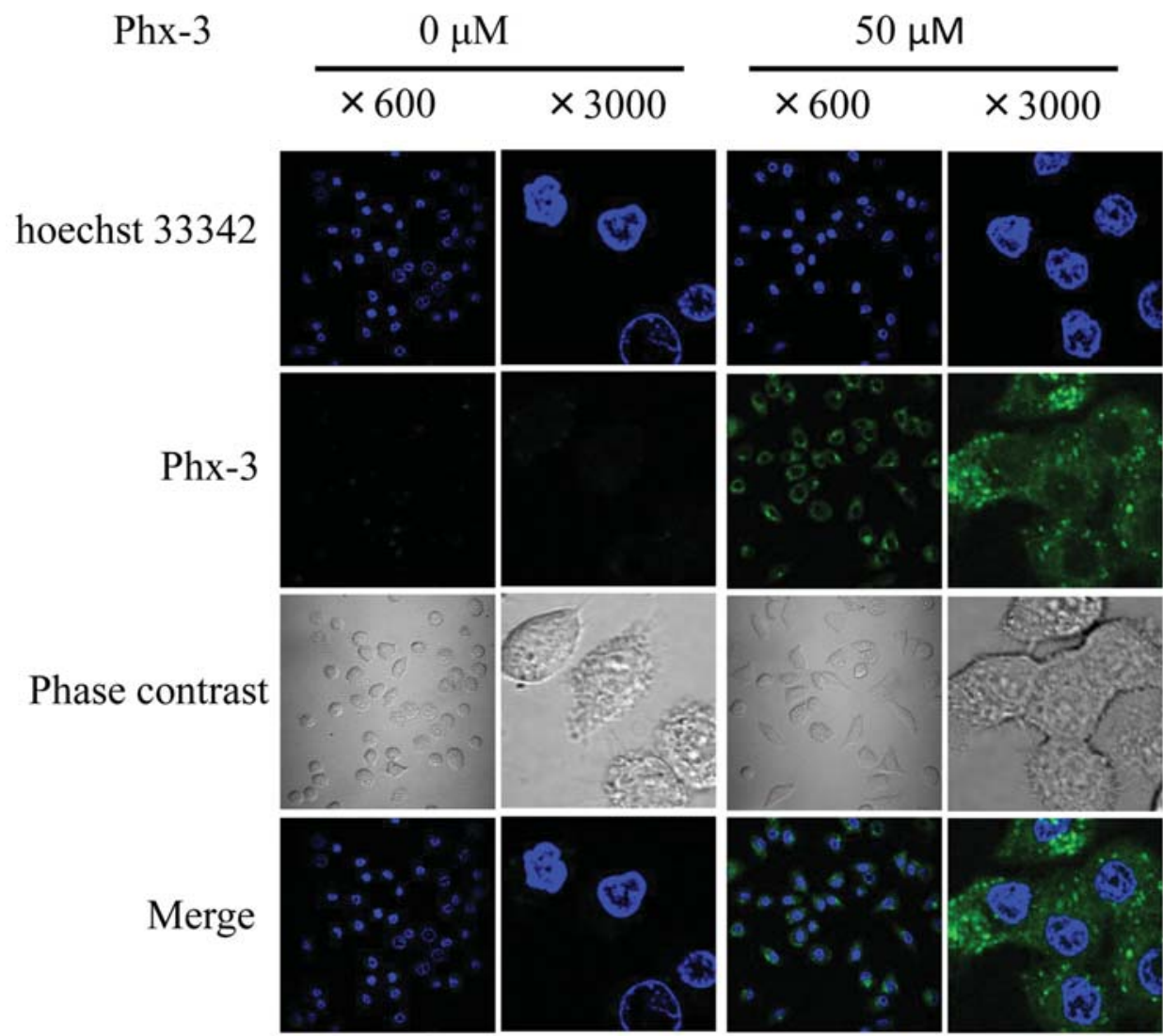

B

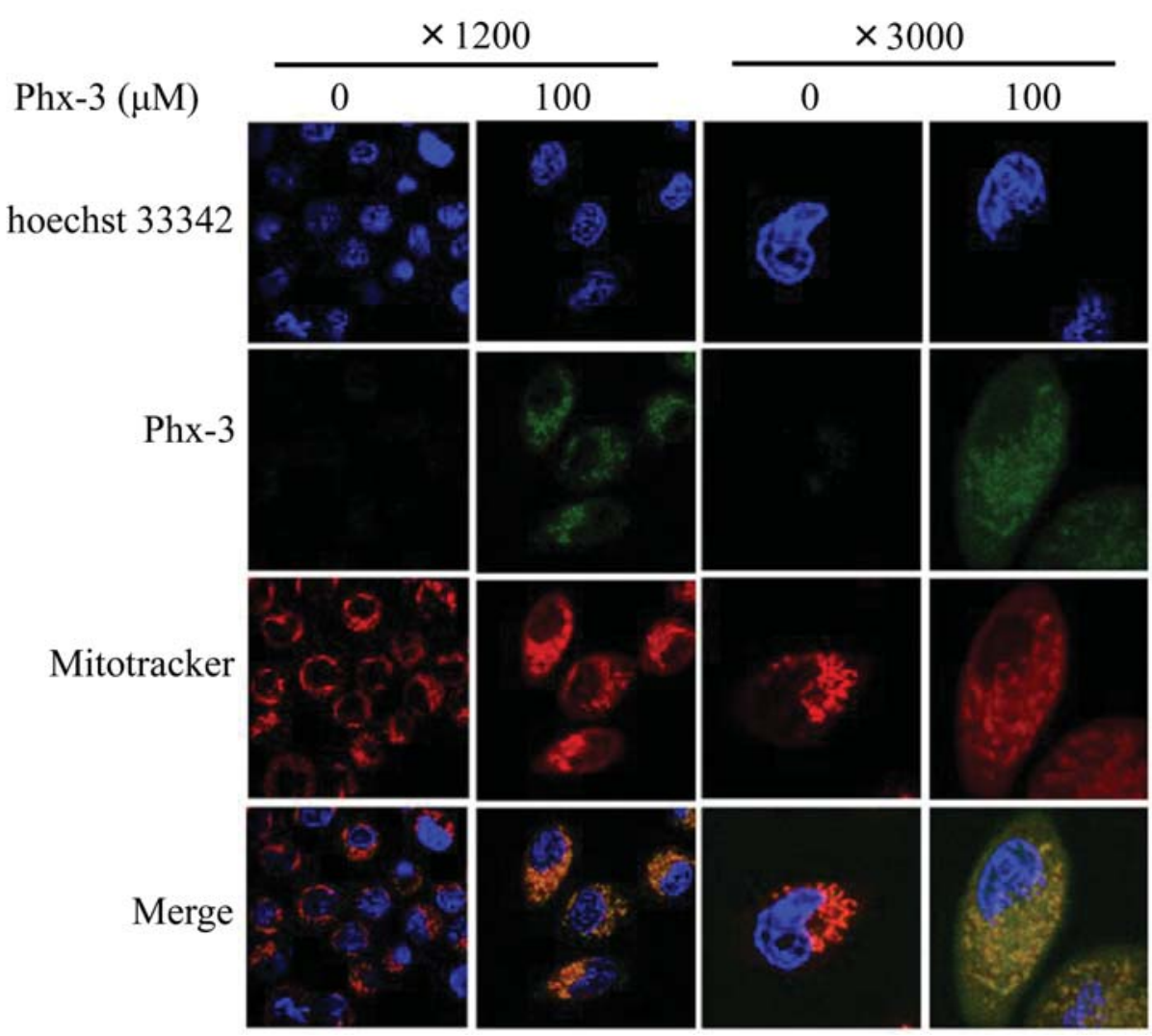

Figure 7. Localization of Phx-3 in A549 cells detected by laser scanning confocal microscopy. After staining of A549 cells with Phx-3, Hoechst 33432 or Mitotracker, the localization of these compounds in A549 cells were detected by LSCM (magnification, x600, x1,200 or x 3,000). (A) A549 cells were treated with $50 \mu \mathrm{M}$ Phx-3 for 45 min. Hoechst 33432 was used to stain the nuclei in A549 cells. Green fluorescence in the merged sample represents the distribution of Phx-3. (B) A549 cells were treated with $100 \mu \mathrm{M}$ Phx-3 or Mitotracker. Mitotracker was used to stain the mitochondria, and Hoechst 33432 was used to stain the nuclei in A549 cells. Green fluorescence represents the distribution of Phx-3. Yellow fluorescence in the merged sample with Mitotracker and Phx-3 shows the localization of Phx-3. 


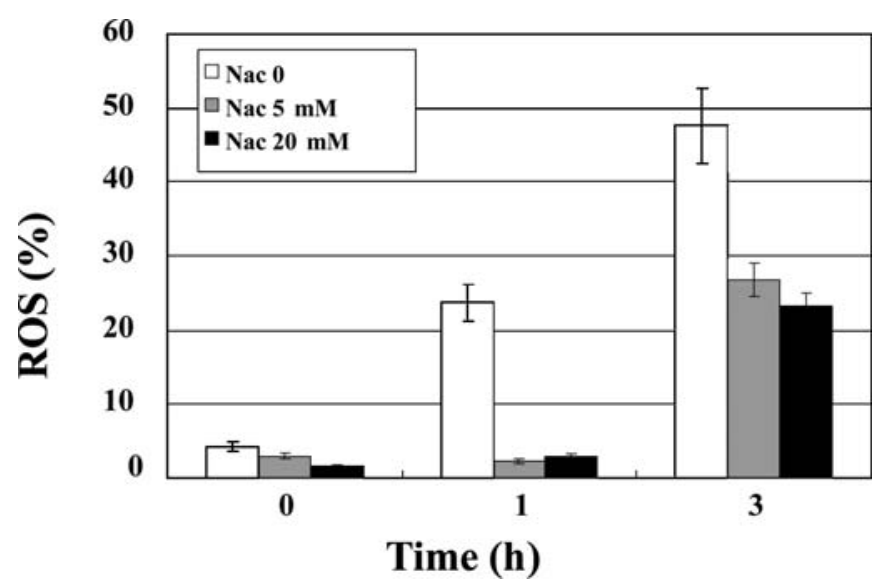

Figure 8. Phx-3-induced ROS production in A549 cells. A549 cells were treated with $7 \mu \mathrm{M}$ Phx-3 for 0,1 and $3 \mathrm{~h}$, in the presence or absence of 5 or $20 \mathrm{mM}$ Nac. Then, ROS production in the cells were analyzed according to the method in Materials and methods.

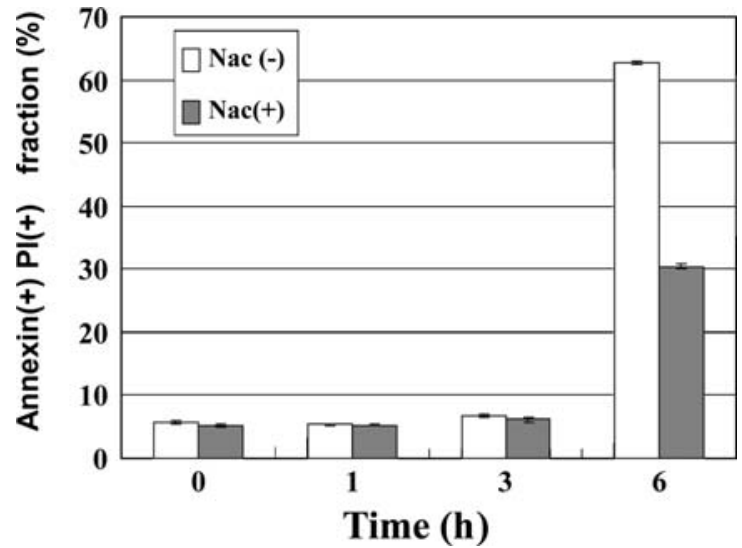

Figure 9. Effects of Nac on Phx-3-induced apoptosis in A549 cells. A549 cells were treated with $7 \mu \mathrm{M}$ Phx-3 for $6 \mathrm{~h}$ in the presence or absence of $5 \mathrm{mM}$ Nac. Then, the populations of late apoptotic cells (annexin $\mathrm{V}^{+} / \mathrm{PI}^{+}$) in A549 cells were examined by flow cytometry.

A

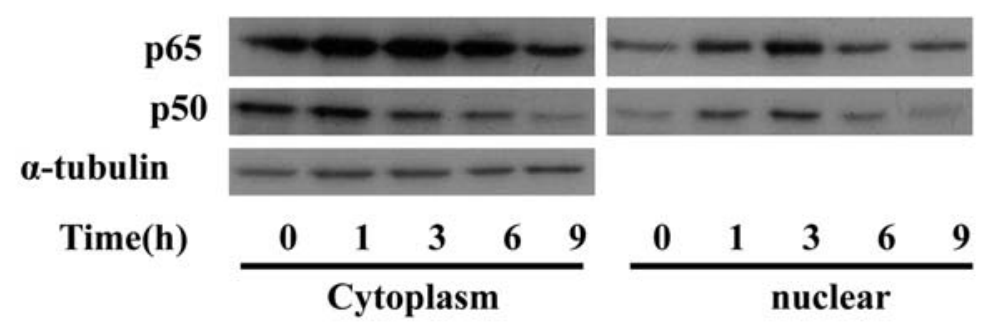

B

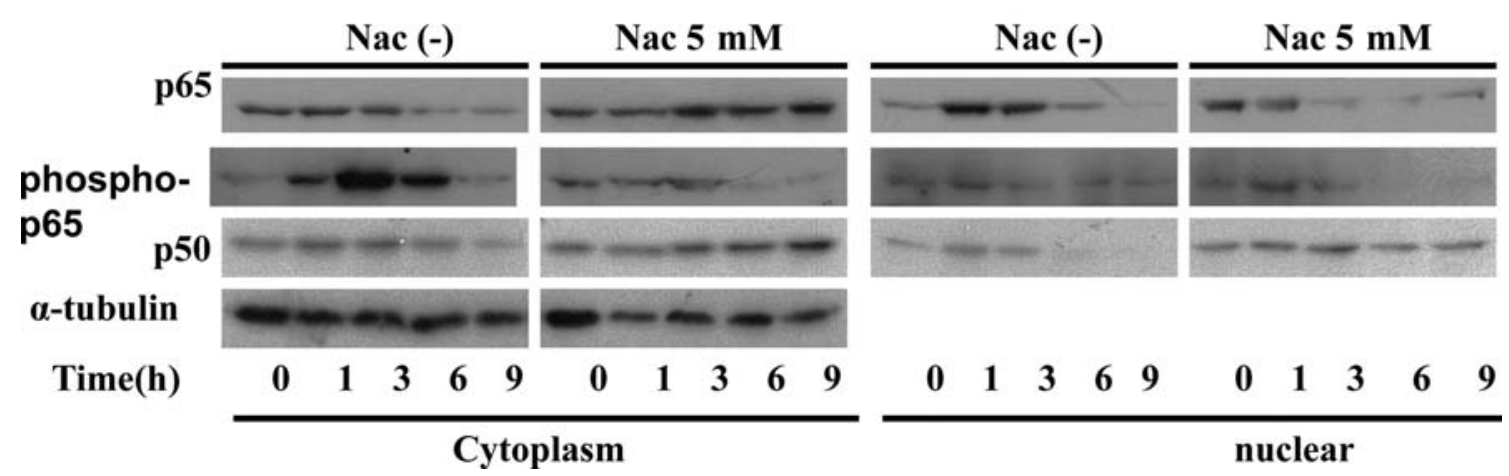

Figure 10. Immunoblot analysis of the levels of NF- $\mathrm{BB}$ components in the cytosol and the nucleus extracted from A549 cells treated with $7 \mu \mathrm{M}$ Phx-3 in the presence or absence of $5 \mathrm{mM}$ Nac for $9 \mathrm{~h}$. Cytosolic and nuclear fractions of p65, p50, p-p65 and $\alpha$-tubulin were detected as described in Materials and methods. Protein concentrations were normalized according to $\alpha$-tubulin levels. (A) The level of components (p65 and p50) of NF-кB in the cytoplasm and nucleus in A549 cell treated with Phx-3. (B) Effect of Nac on the levels of p65, p-p65 and p50 in the cytoplasm and nucleus in A549 cells treated with Phx-3.

that the level of p50 in the cytosol decreased $3 \mathrm{~h}$ after treatment of Phx-3, and both the level of p65 and p50 in the nucleus increased significantly after $1 \mathrm{~h}$. These results indicate that the translocation of NF- $\mathrm{KB}$ heterodimer p65-p50 to the nucleus occurred in A549 cells, 1-3 h after treatment with Phx-3.

To investigate whether this $\mathrm{NF}-\kappa \mathrm{B}$ activation is mediated by the generation of ROS, A549 cells were treated with $7 \mu \mathrm{M}$ Phx-3 in the presence or absence of $5 \mathrm{mM} \mathrm{Nac}$, a scavenger of ROS, and the changes in p65, p-p65 and p50 in the cytosol and the nucleus extracted from the cells were detected by immunoblotting (Fig. 10B). It was found that in the presence of Nac, the level of p65 did not alter in the cytoplasm for $9 \mathrm{~h}$, but decreased after $1 \mathrm{~h}$, in the nucleus. The level of p-p65, which increased markedly after $3 \mathrm{~h}$ in the cytoplasm of A549 cells with Phx-3 in the absence of Nac, did not alter after $3 \mathrm{~h}$, in the presence of Nac. These results suggest that ROS production induced by $\mathrm{Phx}-3$ may be implied in the activation of NF- $\mathrm{BB}$ in A549 cells.

We further studied whether NF- $\mathrm{B}$ activation is involved in apoptosis in A549 cells treated with Phx-3. Fig. 11 represents the flow cytometric analysis of A549 cells treated with Phx-3 in the presence or absence of Bay 11-7082, an NF-кB inhibitor or MG132, a proteasome inhibitor that prevents the degradation of the phosphorylated I $\mathrm{B} \alpha$. Both Bay 11-7082 and MG132 increased the population of late apoptotic cells 


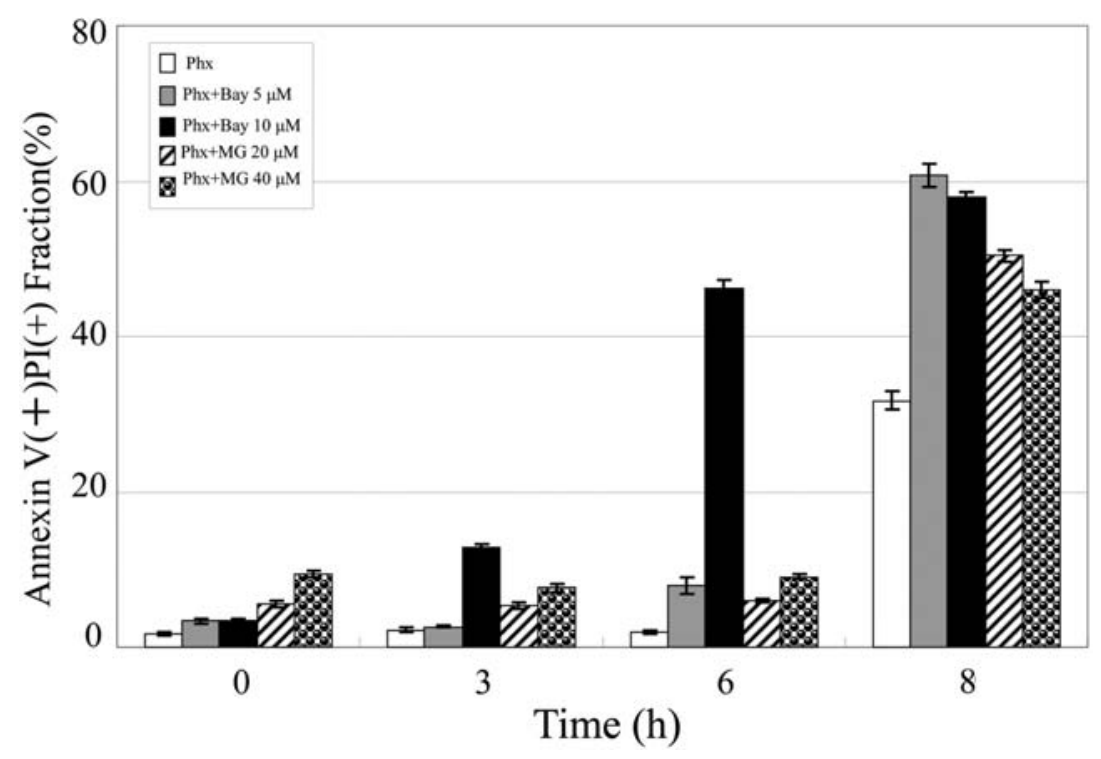

Figure 11. Effects of NF-кB inhibitors on apoptosis in A549 cells treated with Phx-3. A549 cells were treated with $7 \mu \mathrm{M}$ Phx-3 for 9 h with or without NF- $\mathrm{B}$ inhibitors, including MG-132 (5 or $10 \mu \mathrm{M})$ and Bay $11-7082(20$ or $40 \mu \mathrm{M})$. The population of the late apoptotic cells (annexin $\left.\mathrm{V}^{+} / \mathrm{PI}^{+}\right)$in $\mathrm{A}_{549}$ cells was estimated by a flow cytometric method described in Materials and methods.

(annexin $\mathrm{V}^{+} / \mathrm{PI}^{+}$) in a dose- and time-dependent manner. This result suggests that $\mathrm{NF}-\kappa \mathrm{B}$ activation counteracts the induction of apoptosis in A549 cells with Phx-3.

\section{Discussion}

The present study found that Phx-3 suppressed the viability of human lung adenocarcinoma cell line A549 at a much lower concentration than arsenite and CDDP (Fig. 2) and that this suppression was the result of apoptosis induction in the cells caused by Phx-3 (Figs. 3 and 9). Therefore, it is important to investigate the mechanism for the Phx-3induced apoptosis in A549 cells for the possible application of Phx-3 to treating lung cancer, the annual incidence of which is increasing.

Accumulation of Phx-3 in the cytoplasm and the mitochondria (Fig. 7A and B) and decrease of pHi (Figs. 5 and 6) were the initial prominent events observed in A549 cells with $\mathrm{Phx}-3$. As for $\mathrm{pHi}$, intracellular alkalinization has been recognized as a common feature of proliferative processes (2). It has also been suggested that in cancer cells, pHi is increased (5). In spite of these reports, the systemic evaluation of pHi has not been reported for a variety of cancer cells. We found in the present study that the pHi of A549 cells (pH 7.63) was much higher than that of normal cells (usually $\mathrm{pH}$ 7.2), Ehrlich's ascites tumor EHR2 cells (pHi 7.3) (6), and HL60 cells (pHi 7.4) (7). The present result is consistent with the finding of Goossens et al (7) that the pHi of P388 cells is 7.6, and our previous finding (8) that the pHi of human epidermoid carcinoma cell line (KB-3-1) is 7.65 and that of the human chronic myeloid leukemia cell line (K562) is 7.8. Such increased pHi seems to favor for proliferative process and oncogene transformation $(9,10)$ and may be consistent with the enhanced glycolytic pathway in cancer cells, which is known as the Warburg effect (30). The actual cause of the Warburg effect is, however, enigmatic. Since phosphofructokinase, a key enzyme of the glycolytic pathway, is very sensitive to changes in $\mathrm{pH}$ [i.e., its activity is slowed by acidic $\mathrm{pH}$ and promoted by alkaline $\mathrm{pH}$ (31)], higher pHi in cancer cells enhances glycolysis in the cells and explains the mechanism of the Warburg effect.

From this perspective, drugs to induce intracellular acidification of cancer cells may be advantageous for treating cancer. We found that the pHi in A549 cells was extensively decreased (from 7.65 to 7.1 ) within 30 min by adding $7 \mu \mathrm{M}$ Phx-3 to the cells (Fig. 5) and that acidification continued for $3 \mathrm{~h}$ (Fig. 6). Such a rapid and sustained decrease of pHi in A549 cells induced by Phx-3 may perturb the intracellular homeostasis and metabolism as well as cause dysfunction of mitochondria and the activation of endonuclease II, leading to apoptotic death (11-12). According to Hendrich et al (32), phenoxazine molecules are located close to the polar/apolar interface of lipid bilayers and weakly interact with lipid bilayers, altering the lipid phase properties of the cellular and mitochondrial membranes. We found that Phx-3 localized in mitochondria (Fig. 7A and B). Therefore, it is conceivable that the decrease of $\mathrm{pHi}$ in A549 cells may be due to the perturbation of the lipid bilayers of the mitochondrial membranes.

It has been suggested $(2,11,12)$ that drastic changes in pHi for a short period accompany the depolarization of mitochondria, induce ROS production and finally induce apoptosis in A549 cells. We found that ROS was significantly produced $1 \mathrm{~h}$ after adding Phx-3 to A549 cells (Fig. 8), with subsequent suppression of viability (Fig. 2), cell cycle arrest at the $G_{1}$ phase (Fig. 4A-C), accumulated population of cells with the sub- $\mathrm{G}_{1}$ phase (Fig. 4A-C), and cellular apoptosis (Figs. 3 and 9) after 3 h. In addition, Nac, a scavenger of ROS, extensively prevented apoptosis induction (Fig. 9). Thus, it can be concluded that ROS is the most pivotal molecule that induces apoptosis in A549 cells treated with Phx-3.

It has also been found that ROS activates NF-кB, which exists as p50-RelA(p65) dimer and is bound to IкB $\alpha$, an inhibitory protein of NF- $\mathrm{KB}$ in the cytosol. Thus, ROS plays 
a crucial role in the proliferation, protection from apoptosis, and drug resistance of cancer cells (33). The activation of $\mathrm{NF}-\kappa \mathrm{B}$ accompanying the phosphorylation of $\mathrm{I} \kappa \mathrm{B} \alpha$, the rapid decomposition of the phosphorylated I $\mathrm{I} \mathrm{B} \alpha$ by the proteasome, and the translocation of NF- $\mathrm{KB}$ from the cytosol to the nucleus promote the transcription of Bcl-family proteins and inhibitor of apoptosis proteins (IAP), preventing cellular apoptosis (28). Therefore, the activation of NF- $\mathrm{BB}$ is involved in the antiapoptotic behavior of the cells. However, it has been indicated that anticancer drugs such as camptothecin and etoposide were able to activate $\mathrm{NF}-\kappa \mathrm{B}$ either by increasing oxidative stress and calcium concentration in the cytoplasm or by inducing genotoxic stress, leading to the induction of cellular apoptosis $(28,34)$. Thus, activated NF$\mathrm{\kappa B}$ seems to act in an antiapoptotic or proapoptotic manner, regarding cellular apoptosis (35). In the present study, the translocation of the activated $\mathrm{NF}-\kappa \mathrm{B}$ occurred $1 \mathrm{~h}$ after treating A549 cells with $7 \mu \mathrm{M}$ Phx-3 (Fig. 10A), concomitant with the increased production of ROS (Fig. 8). It was found that, in the presence of Nac, a scavenger of ROS, the activation of NF- $\kappa B$ and the translocation of activated NF- $\kappa B$ were significantly prevented in A549 cells treated with Phx-3 after $1 \mathrm{~h}$ (Fig. 10B). Considering these results, it is possible that the translocation of NF- $\mathrm{KB}$ to the nucleus is due to the accumulation of ROS in A549 cells treated with Phx-3. However, cell apoptosis was significantly enhanced when MG132, a proteasome inhibitor or Bay 11-7082, an NF- $\mathrm{B}$ inhibitor that prevents the degradation of $\mathrm{I} \kappa \mathrm{B}$ and the activation of NF- $\kappa \mathrm{B}$, was added to A549 cells treated with Phx-3 (Fig. 11); thus, it seems unlikely that the activation of $\mathrm{NF}-\kappa \mathrm{B}$, which occurred after $1 \mathrm{~h}$ in A549 cells treated with Phx-3 (Fig. 10A), acted toward the promotion of apoptosis. A similar result was indicated in primary adult T-cell leukemia cells treated with Bay 11-7082 (33). Chen et al (29) demonstrated that adriamycin-induced NF- $\kappa \mathrm{B}$ protected A549 cells against apoptosis caused by this drug. Judging from these results, it is likely that the activation of NF- $\mathrm{NB}$ is involved in the antiapoptotic mechanism in A549 cells treated with $\mathrm{Phx}-3$, rather than in the proapoptotic mechanism, and resists the apoptotic behavior of A549 cells induced by Phx-3.

We demonstrated the localization of Phx-3 in A549 cells for the first time (Fig. 7A and B). Namely, A549 cells treated with Phx-3 for 30 min predominantly located in the cytoplasm and in the mitochondria, suggesting that the cytoplasmic and mitochondrial events were perturbed by Phx-3 in the cells. Phx-3 did not seem to permeate to the nucleus in our study; however, the possibility that a small amount of $\mathrm{Phx}-3$ permeated to the nucleus could not be ruled out. Phx-3 intercalates to DNA in a cell-free system (36) as actinomycin D does (20), but whether the function of the genomic DNA was affected by the intercalation of Phx-3 in A549 cells is unclear.

Human lung cancer is intractable to chemotherapy; therefore, the development of drugs to treat this lethal disease is urgently needed. In the present study, we demonstrated that Phx-3 is capable of suppressing the viability of human lung adenocarcinoma cell line A549 efficiently (Fig. 2), and of inducing apoptosis of the cells (Fig. 3). Phx-3 has been found to exert less adverse effects on mice (23). Therefore, $\mathrm{Phx}-3$ may be a potential candidate for treating lung cancer in the future.

\section{Acknowledgements}

The present study was supported in part by funds from the Private University Strategic Research-Based Support Project (Molecular Information-based Intractable Disease Research Project) from the Ministry of Education, Culture, Sports, Science and Technology of Japan (2008-2012).

\section{References}

1. Barry MA, Reynold JE and Eastman A: Etoposide-induced apoptosis in human HL-60 cells is associated with intracellular acidification. Cancer Res 53: 2349-2357, 1993.

2. Lagadic-Gossmann D, Huc L and Lecureur V: Alterations of intracellular $\mathrm{pH}$ homeostasis in apoptosis: origins and roles. Cell Death Differ 11: 953-961, 2004

3. Tsuda S, Kakinuma K and Minakami S: Intracellular $\mathrm{pH}$ of red cells stored in acid citrate dextrose medium. Experientia 28: 1481-1482, 1972.

4. Tomoda A, Tsuda-Hirota S and Minakami S: Glycolysis of red cells suspended in solution of impermeable solutes. J Biochem 81: 697-701, 1977.

5. Izumi $H$, Torigoe $T$, Ishiguchi $H$ Uramoto $H$, Yoshida $Y$, Tanabe $M$, Ise T, Murakami T, Yoshida T, Nomoto M and Kohno K: Cellular $\mathrm{pH}$ regulators: potentially promising molecular targets for cancer chemotherapy. Cancer Treat Rev 29: 541-549, 2003.

6. Litman T, Pedersen SF, Karamhoft B, Skovsgaad T and Hoffmann EK: $\mathrm{pH}$ regulation in sensitive multidrug resistant Ehrlich ascites tumor cells. Cell Physiol Biochem 8: 37-50, 1998.

7. Goossens J-F, Henichrt J-P, Dassonneville L, Facompre M and Bailly C: Relation between intracellular acidification and camptothecin-induced apoptosis in leukemia cells. Eur J Pharm Sci 10: 125-131, 2000.

8. Che X-F, Akiyama S and Tomoda A: Suppression of the proliferation of cancer cell lines, KB-3-1 and K562 cells preceded by a decrease in intracellular $\mathrm{pH}$ caused by phenoxazine derivatives. Oncol Rep 19: 1253-1258, 2008.

9. Shrode LD, Tapper H and Grinstein S: Role of intracellular $\mathrm{pH}$ in proliferation, transformation and apoptosis. J Bioenerg Biomembr 29: 293-299, 1997.

10. Putney LK, Denker SP and Barber BL: The changing face of the $\mathrm{Na}^{+} / \mathrm{H}^{+}$exchanger, NHE1: structure, regulation and cellular actions. Annu Rev Pharmacol Toxicol 42: 527-552, 2002.

11. Matsuyama S, Liopis J. Deveraux QI, Tsien RY and Reed JC: Changes in intramitochondrial and cytosolic pH: early events that modulate caspase activation during apoptosis. Nat Cell Biol 2: 318-325, 2000.

12. Matsuyama S and Reed JC: Mitochondria-dependent apoptosis and cellular pH regulation. Cell Death Differ 7: 1155-1165, 2000.

13. Barry MA and Eastman A: Endonuclease activation during apoptosis. The role of cytosolic $\mathrm{Ca}^{2+}$ and $\mathrm{pH}$. Biochem Biophys Res Commun 186: 782-789, 1992.

14. Flohe L, Brigelius-Flohe R, Saliou C, Traber MG and Packer L: Redox regulation of NF-kappa B activation. Free Radic Biol Med 22: 1115-1126, 1997.

15. Hayakawa M, Miyashita H, Sakamoto I, Kitagawa M, Tanaka H, Yasuda $\mathrm{Y}$, Karin $\mathrm{M}$ and Kikugawa K: Evidence that reactive oxygen species do not mediate NF- $\mathrm{KB}$ activation. EMBO J 22: 3356-3366, 2003.

16. Sheridan JP, Marsters SA, Pitti RM, Gumey A, Skubatch M, Baldwin D, Ramakrishnan L, Gray CL, Baker K, Wood WI, Guddard AD, Dodowski P and Ashkenazi A: Control of TRAILinduced apoptosis by a family of signaling and decoy receptors. Science 277: 818-821, 1997.

17. Chen J-J, Chou C-W, Chang Y-F and Chen C-C: Proteasome inhibitors enhance TRAIL-induced apoptosis through the intronic regulation of DR5: involvement of $\mathrm{NF}-\kappa \mathrm{B}$ and reactive oxygen species-mediated p53 activation. J Immunol 180: 30-39, 2008.

18. Tomoda A, Arai S and Ishida R: An improved method for the rapid preparation of 2-amino-4,4 $\alpha$-dihydro- $4 \alpha, 7$-dimethyl-3Hphenoxazine-3-one, a novel antitumor agent. Bioorg Med Chem Lett 11: 1057-1058, 2001.

19. Shimizu S, Suzuki M, Tomoda A. Arai S, Taguchi H, Hanawa T and Kamiya S: Phenoxazine compounds produced by the reactions with bovine hemoglobin show antimicrobial activity against non-tuberculosis mycobacteria. Tohoku J Exp Med 203: 47-52, 2004. 
20. Hollstein U: Actinomycin. Chemistry and mechanism of action. Chem Rev 74: 625-652, 1974

21. Mori H, Honda K, Ishida R, Nohira T and Tomoda A: Antitumor activity of 2 -amino-4,4 $\alpha$-dihydro- $4 \alpha, 7$-dimethyl-3Hphenoxazine-3-one against Meth A tumor transplanted into BALB/c mice. Anticancer Drugs 11: 653-657, 2000.

22. Shimamoto T, Tomoda A, Ishida R and Ohyashiki K: Antitumor effects of a novel phenoxazine derivative on human leukemia cell lines in vitro and in vivo. Clin Cancer Res 7: 704-708, 2001.

23. Miyano-Kurosaki N, Kurosaki K, Hayaashi M, Takaku H, Hayafune M, Shrato K, Kasuga T, Endo T and Tomoda A: 2Aminophenoxazine-3-one suppresses the growth of mouse malignant melanoma B16 cells transplanted into C57BL/6Cr Slc mice. Biol Pharm Bull 29: 2197-2201, 2006.

24. Shirato K, Imaizumi K, Miyazawa K Takasaki A, Mizuguchi J, Che X-F, Akiyama S and Tomoda A: Apoptosis induction preceded by mitochondrial depolarization in multiple myeloma cell line U266 by 2-aminophenoxazine-3-one. Biol Pharm Bull 31: 62-67, 2008.

25. Shirato K, Imaizumi K, Abe A and Tomoda A: Phenoxazine derivatives, 2 -amino-4,4 $\alpha$-dihydro- $4 \alpha, 7$-dimethyl-3Hphenoxazine-3-one and 2-amino-phenoxazine-3-one-induced apoptosis through a caspase-independent mechanism in human neuroblastoma cell line NB-1 cells. Biol Pharm Bull 30: 331336, 2007.

26. Shirato K, Imaizumi K, Abe A and Tomoda A. Phenoxazine derivatives induce caspase-independent cell death in human glioblastoma cell lines, A-172 and U-251. Oncol Rep 17: 201-208, 2007.

27. Kasuga T, Tabuchi T, Shirato K, Imaizumi K and Tomoda A: Caspase-independent cell death revealed in human gastric cancer cell lines, MKN45 and KATO III treated with phenoxazine derivatives. Oncol Rep 17: 409-415, 2007.
28. Janssens $\mathrm{S}$ and Tschopp J: Signals from within: the DNAdamage-induced NF-кB response. Cell Death Differ 13: 773-784, 2006.

29. Chen, W, Wang X, Bai L, Liang X, Zhuang J and Lin Y: Blockage of NF- $\mathrm{BB}$ by IKKb-or RelA-siRNA rather than the $\mathrm{NF}-\kappa \mathrm{B}$ super-suppressor IкB $\alpha$ mutant potentiates adriamycininduced cytotoxicity in lung cancer cells. J Cell Biochem 105: 554-561, 2008.

30. Warburg O: On the origin of cancer cells. Science 24: 309-314, 1956.

31. Ui M: A role of phosphofructokinase in $\mathrm{pH}$ dependent regulation of glycolysis. Biochim Biophys Acta 124: 310-322, 1966.

32. Hendrich AB, Stanczak K, Komorowska M, Motohashi N, Kawase M and Kichalak K: A study on the perturbation of model lipid membranes by phenoxazines. Bioorg Med Chem 14: 5948-5954, 2006

33. Mori N, Yamada Y, Ikeda S, Yamazaki Y, Tsukazaki K, Tanaka K, Tomonaga K, Yamamoto N and Fujii M: Bay11-7-82 inhibits transcription factor NF-kappaB and induces apoptosis of HTLV-1-infected T-cell lines and primary adult T-cell leukemia cells. Blood 10: 1828-1834, 2002.

34. Mikkelsen RB and Wardman P: Biological chemistry of reactive oxygen and nitrogen and radiation-induced signal transduction mechanisms. Oncogene 22: 5734-5754, 2003.

35. Herr I and Debatin K-M: Cellular stress response and apoptosis in cancer therapy. Blood 98: 2603-2613, 2001.

36. Bendic $\mathrm{C}$ and Volanschi E: Molecular modeling of the interaction of some phenoxazone-antitumoral drugs with DNA. Internet Electron J Mol Design 5: 320-330, 2006. 